\title{
Analysis of 4 Tourism Components in Tirosa Park as a New Alternative Tourism in Kupang City
}

\author{
Martarida Bagaihing*, Veronika A. S. M. Flora, Ariance Ana Lasibey \\ Tourism Department \\ Politeknik Negeri Kupang \\ Kupang, Indonesia \\ *eedatha@gmail.com, veronikaflora1986@gmail.com, rinlasibey@gmail.com
}

\begin{abstract}
This study aims to determine the effect of the tourist attraction component on tourist visit and to determine the potential of tourism components that can be developed in Tirosa Park. This research uses a mixed research method namely explanatory sequential design. The results of this study are the tourism components which consist of attraction (X1), accessibility (X2), amenity (X3), and ancillary (Y) which together affect tourist visit (Y) simultaneously. Partially the amenity has no significant effect on tourist visit. The potential tourism components that can be developed in Tirosa Park are nature tourism, culture, and man- made tourism. The component of amenity needs to be added again so that tourists who carry out tourism activities can spend more time there.
\end{abstract}

Keywords-tourism components, potential tourism attractions

\section{INTRODUCTION}

Tourism provides many benefits for the economy of a region [1]. In Indonesia, tourism is considered as one of the mainstay sectors of the country's largest foreign exchange earner in the non-oil and gas sector. In the implementation of regional autonomy, tourism is one alternative that can be utilized by each region as a source of regional revenue. Local governments can develop the potential that exists in their area by considering the quality of tourism products provided.

The city of Kupang is the capital of the East Nusa Tenggara province which is currently managing the city by developing city park that are laid out and equipped with other supporting facilities. The arrangement of this city park becomes interesting and beautiful for the city community and people who live outside the Kupang city area. Every day many people come to visit the city parks.

The level of tourist visits to Kupang city is dominated by domestic tourists but the tourist attractions are still small compared to some other districts in the province of East Nusa Tenggara [2]. It displays the opposite of an area with a high level of tourist visit, but the availability of tourist attractions that are very minimal. Tourists will spend a lot of time in an area that can meet their expectations in traveling. It will have an impact on regional income. The Government of Kupang City can take this opportunity to optimize the existence of existing tourism potential. This is not merely to increase regional income but as an effort to preserve and preserve the natural and cultural environment. If it is associated with the government program that is building city parks as a gathering place for residents to enjoy the beauty of nature, it is necessary to approach it so that its development is right on target and can benefit the community.

Based on the explanation above, the problems that have been identified are (1) how is the effect of tourism components (attraction, accessibility, amenity, and ancillary) simultaneously on tourist visit in Tirosa Park? (2) how is the effect of tourism components (attraction, accessibility, amenity, and ancillary) partially on tourist visit in Tirosa Park? (3) What are the potential tourism attractions that can be developed in Tirosa Park so that they become a new alternative for tourism? The purposes of this study are (1) To find out how the effect of tourism components to tourist visit in Tirosa Park and (2) To find out the potential of tourist components that can be developed in Tirosa Park.

\section{REVIEW OF LITERATURE}

\section{A. Tourist Attraction}

The tourism attraction is anything that has a uniqueness, beauty, and value in the form of natural, cultural, and manmade diversity that is the target or destination of tourist visits [3]. Tourists visit a place because there is something interesting and encourage tourists to come [4]. A tourist attraction does not only provide something interesting but how it can be organized so that it attracts tourists to come to do tourist activities. There are three types of tourist attractions, namely natural attractions, cultural tourism attractions and special interests [5]. It can be said that tourist attraction is everything that is unique and interesting provided by nature, culture, and also man-made products that can encourage humans to enjoy it.

\section{B. Tourism Components}

The development of tourism area must be able to provide a tourism components consisting of tourist attraction, accessibility, Amenity and ancillary, known as the tourism 4A 
components. Fig. 1 shows 4 tourism components that have synergy each other. Tourist attractions consist of natural, cultural and special tourist attractions, where tourists will reach the area to meet the needs of the desired tourist attraction. In order to reach the area, transportation facilities and infrastructure need to be provided to fulfil accessibility facilities.

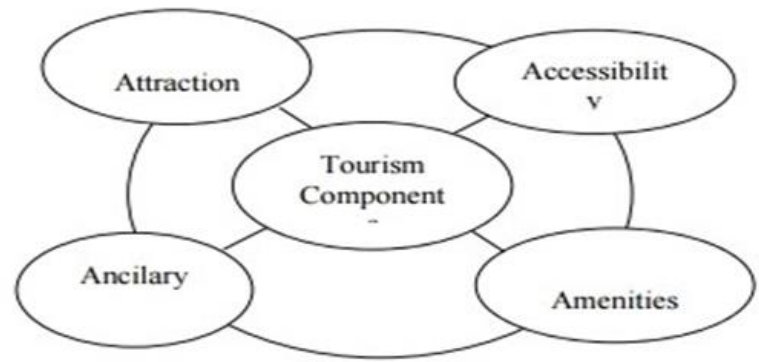

Fig. 1. Tourist destination components.

While in the tourist area, tourists certainly need to eat, drink and stay. Therefore, it is necessary to provide the fulfilment of accommodation needs as security services. Cooperation is also needed from various parties such as associations or the tourism community in order to support the quality of tourism services provided. To bring together the cooperation of all parties in question it needs to be funded through the provision of Ancillary components [6].

Attraction is all kinds of movable or immovable objects that have tourist attractions, are worth offering and selling to tourists. Accessibility is the infrastructure that causes tourists to visit the tourist attraction. Amenity is all kinds of facilities that support the development of tourism. Ancillary covers the existence of various organizations to facilitate and encourage the development and marketing of tourism in these destinations.

Tourists are parties who get and use every component of tourism. Therefore, it is necessary to know the opinion of visitors about the services provided so as to provide input on aspects of what tourism needs to be considered again in the development and management of the place. In addition, visitor responses can also be input for the development of potential attractions in the place.

\section{Hypothesis}

$\mathrm{H} 1=4$ tourism components consist of attraction (X1), accessibility (X2), amenity (X3), and ancillary (X4) simultaneously influencing tourist visit in Tirosa Park and H2 $=4$ tourism components consist of attraction (X1), accessibility (X2), amenity (X3), and ancillary (X4) have a partial effect on tourist visit to Tirosa Park.

TABLE I.

RESEARCH CONCEPT

\begin{tabular}{|c|c|c|c|c|}
\hline No & Variable & Operational Definition of Variable & Indication & Likert Scale \\
\hline 1 & Attraction & something that has an attraction [7] & $\begin{array}{l}\text { Natural attraction } \\
\text { Cultural attraction } \\
\text { Man made attraction }\end{array}$ & $\begin{array}{l}5=\text { Strongly agree } \\
4=\text { Agree } \\
3=\text { Neutral } \\
2=\text { Disagree } \\
1=\text { Strongly disagree }\end{array}$ \\
\hline 2 & Accessibility & the level of ease to achieve a place [6] & $\begin{array}{l}\text { Transportation infrastructure } \\
\text { Transportation service }\end{array}$ & $\begin{array}{l}5=\text { Strongly agree } \\
4=\text { Agree } \\
3=\text { Neutral } \\
2=\text { Disagree } \\
1=\text { Strongly disagree }\end{array}$ \\
\hline 3 & Amenity & Supporting facilities that tourists can use during their tour [6] & $\begin{array}{l}\text { Food and beverage } \\
\text { Hotels } \\
\text { Toilet } \\
\text { Parking area }\end{array}$ & $\begin{array}{l}5=\text { Strongly agree } \\
4=\text { Agree } \\
3=\text { Neutral } \\
2=\text { Disagree } \\
1=\text { Strongly disagree }\end{array}$ \\
\hline 4 & Ancillary & $\begin{array}{l}\text { keeping track of the availability of an organization or people managing the } \\
\text { destination [7] }\end{array}$ & $\begin{array}{l}\text { Government } \\
\text { Street vendor association }\end{array}$ & $\begin{array}{l}5=\text { Strongly agree } \\
4=\text { Agree } \\
3=\text { Neutral } \\
2=\text { Disagree } 1=\text { Strongly disagree }\end{array}$ \\
\hline 5 & Tourist Visit & $\begin{array}{l}\text { People's decisions to make visits that are influenced by stimuli from } \\
\text { outside themselves, either in the form of marketing stimuli or other } \\
\text { environments stimuli until the decision to visit [8] }\end{array}$ & $\begin{array}{l}\text { searching for information } \\
\text { alternative assessment } \\
\text { the act of visiting } \\
\text { behavior after visiting }\end{array}$ & $\begin{array}{l}5=\text { Strongly agree } \\
4=\text { Agree } \\
3=\text { Neutral } \\
2=\text { Disagree } 1=\text { Strongly disagree }\end{array}$ \\
\hline
\end{tabular}

\section{METHODS}

This study uses a mix method research with sequential data collection techniques, namely a combination of quantitative and qualitative research methods respectively [9]. The data collection techniques used a questionnaire with a Likert scale given to 100 visitors to Tirosa park and triangulation, namely observation, in-depth interviews, and documentation. This research begins by finding out the relationship of the tourism components toward tourist visits by distributing questionnaires to 100 visitors as sample. From the results of the analysis of the questionnaire calculations and also the results of interviews with street vendors, visitors and the government, it can determine the potential tourist attractions in Tirosa Park. 


\section{DISCUSSION}

Tirosa Park is a green open space that is located to be passed before entering the City of Kupang. This park is one of the icons of Kupang City and many visitors come to spend time in this place.

\section{A. The Effect of Tourism Components to Tourist Visit}

To answer the first problem of this study can be seen in the $\mathrm{F}$ test (Anova).

TABLE II. F TEST RESULT

ANOVA $^{\mathrm{a}}$

\begin{tabular}{|c|l|l|l|l|l|c|}
\hline \multicolumn{2}{|c|}{ Model } & $\begin{array}{c}\text { Sum of } \\
\text { Squares }\end{array}$ & df & $\begin{array}{c}\text { Mean } \\
\text { Square }\end{array}$ & F & Sig \\
\hline \multirow{2}{*}{1} & Regression & 340.633 & 4 & 85.158 & 546.353 & $.000^{\mathrm{b}}$ \\
\cline { 2 - 7 } & Residual & 14.807 & 95 & .156 & & \\
\cline { 2 - 7 } & Total & 355.440 & 99 & & & \\
\hline
\end{tabular}

a. Dependent variable: Tourist Visit

b. Predictors (Constant), Ancillary (X4), Amenity (X3), Accessibility (X2), Attraction (X1)

Table 2 shows that the four independent variables simultaneously influence the variable of tourist visits. It can be seen from the result that the significant value is 0.00 . This significant value is less than the significant value of 0.05 . It can be concluded that hypothesis 1 is accepted, namely the variable Attraction, Accessibility, Amenity, and Ancillary simultaneously influencing tourist visits. By accepting the first hypothesis, it has answered the first problem of this study, namely, the contraction, accessibility, amenities, and ancillary influential simultaneously on tourist visits.

To answer the second problem, namely how the influence of Attraction, Accessibility, Amenity, and Ancillary variables on tourist visit can be seen below.

\section{TABLE III. T TEST RESULT}

\begin{tabular}{|c|c|c|c|c|c|c|}
\hline \multicolumn{7}{|c|}{ Coefficients $^{\mathrm{c}}$} \\
\hline & \multirow[b]{2}{*}{ Model } & \multicolumn{2}{|c|}{$\begin{array}{c}\text { Unstandardized } \\
\text { Coefficients }\end{array}$} & \multirow{2}{*}{\begin{tabular}{|c|}
$\begin{array}{c}\text { Standardized } \\
\text { Coefficients }\end{array}$ \\
Beta \\
\end{tabular}} & \multirow[b]{2}{*}{$\mathbf{t}$} & \multirow[b]{2}{*}{ Sig. } \\
\hline & & B & Std. Error & & & \\
\hline \multirow[t]{5}{*}{1} & (Constant) & -1.315 & 475 & & $-2,769$ & .007 \\
\hline & Attractions (X1) & .237 & .057 & .403 & 4,182 & .000 \\
\hline & $\begin{array}{l}\text { Accessibility } \\
\text { (X2) }\end{array}$ & .234 & .046 & .330 & 5.123 & .000 \\
\hline & Amenity (X3) &,- 030 & .025 &,- 053 & $-1,177$ & .242 \\
\hline & Ancillary (X4) & .365 & .105 & .1010 & 3,486 & .001 \\
\hline
\end{tabular}

c. Dependent variable: Tourist Visit (Y)

From table 3 it shows that the Attraction, Accessibility, and Ancillary variables influence tourist visits because they have a significance value below 0.05 . Amenity variable does not affect tourist visits because it has a significant value of more than 0.05 . The significant value of the Amenity variable is 0,24 . The amenity variable has no effect due to the lack of supporting facilities in Tirosa Park.
Seen from the $\mathrm{R}$ Square test (Coefficient Determination test) in table 4 below shows the contribution of independent variables namely attraction, accessibility, amenities, and ancillary to the dependent variable of $77 \%$. This means that around $23 \%$ is influenced by other variables outside the scope of this research.

TABLE IV. COEFFICIENTS DETERMINATION RESULT

\begin{tabular}{|l|c|l|l|c|}
\hline Model & R & R Square & $\begin{array}{c}\text { Adjusted R } \\
\text { Square }\end{array}$ & $\begin{array}{c}\text { Std. Error of the } \\
\text { Estimate }\end{array}$ \\
\hline 1 & $878^{\text {a }}$ & .770 & .757 & 1.39480 \\
\hline \multicolumn{5}{|c|}{ a. Predictors (Constant), Ancillary (X4), Amenity (X3), Accessibility (X2), } \\
Attraction (X1)
\end{tabular}

\section{B. Potential Tourism Components}

Every visitor wants to be able to meet their needs when visiting a tourist destination. With the quality of the tourism component it can attract people to visit. To answer the third problem, there are the tourism components that can be developed at Tirosa Park.

1) Attractions: Tirosa Park has some uniqueness and beauty that can be developed as natural, cultural, and man made tourist attractions. Based on the results of observations and interviews, the natural tourist attraction of Tirosa Park is a gathering area surrounded by plants and trees. Another interesting thing is that at night people can relax while looking directly at the starry sky. Tirosa park also has monument tirosa which has historical significance. Monument tirosa is an acronym for Timor, Rote, Sabu which tells the history of the union of Kupang which has a wide geographical area. There are 3 statues that have become icons of this monument, which are 3 important community figures who came from Timor, Rote, and Sabu. In addition to natural and cultural attractions, this park also has man made tourist attraction, namely people who come to take selfies because there are lights with bright and colored lighting.

2) Accessibility: The accessibility component to this place is good enough because it is located in the city center so that the road conditions are good and also passed by public transportation. For tourists who have just come to Kupang City, they can access it quickly because to enter Kupang City by air first pass this park with good road conditions.

3) Amenity: Based on current conditions, Tirosa Park arrangement is still lacking with supporting facilities. Several supporting facilities that do not exist and are still lacking, such as nothing public toilets in the Tirosa park area, the absence of adequate parking lots, the number of bins that are still small.

4) Ancillary: The tourism activities that take place in this park have not been organized professionally. Because this park is a green open space, the management of this park is still carried out by the Cleaning and Gardening Service of Kupang 
City, which is in charge of paying attention to the condition of plants and cleanliness in the garden area. In addition there is also an organization of street vendors known as mobile coffee traders (Kopling) who sell in the garden area who also pay attention to the cleanliness of this area while they are selling.

\section{CONCLUSION}

- There is simultaneously the tourism component has an effect on tourist visits where attraction (X1), accessibility (X2), amenity (X3), and ancillary (X4) on tourist visits $(\mathrm{Y})$ have a significant value of 0.00

- There is partially the effect of the tourism components on tourist visit, namely attractions (X1) 0.00, accessibility (X2) 0.00, amenities (X3) 0.242, and ancillary (X4) 0.001. The contribution of the independent variables, namely attractions, accessibility, amenity, and ancillary to the dependent variable was $77 \%$

- Tirosa Park has potential natural, cultural, and artificial tourist attractions. This garden has a garden view with an open sky roof which makes the place to relax more attractive. In addition, there is a Tirosa monument which has historical significance from the merging of the regions in Kupang. The area around the park is also used as a place to take pictures because of the view from the colourful lights.

\section{REFERENCES}

[1] I.G.B. Arjana, Geography of Tourism and Creative Economy. Depok: Rajawali Pers Publisher, 2017.

[2] Official Website of the NTT Province Government: www.nttprov.go.id

[3] Law No.10 of 2009 concerning Tourism

[4] B. Bagyono, Tourism and Hospitality. Bandung: Publisher Alfabeta, 2014.

[5] I. Inskeep and E. Edward, Tourism Planning, An Integreted and Sustainable Development Approach. Canada: Publisher John Wiley, 1991.

[6] A.G. Sugiama, "Tourism Asset Development Framework from the Triple Halix Model," Journal of Business Orations, Xth Edition, pp. 34 47, November 2013.

[7] S. Sugiama and T. Adriyanto, "The Aanalysis of Potential 4A's Tourism Component in The Selasari Rural Tourism, Pangandaran, West Java," Asian Tourism Forum, Atlantis Perss, pp. 138-144, 2016.

[8] P. Kotler and G. Armstrong, Principles of Marketing. Jakarta: Erlangga, 2006.

[9] S. Sugiyono, Quantitative Research Methods, Qualitative, and R \& D. Bandung: Publisher Alfabeta, 2019. 